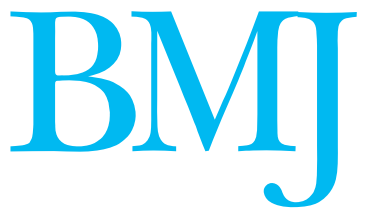

\title{
The national service framework for children
}

\author{
Is about making maternal and child health a priority, not a luxury
}

$\mathrm{T}$ he national service framework for children, young people, and maternity services is the culmination of a process started three years ago and has been heavily influenced by the Kennedy and Laming reports. ${ }^{1-3}$ That it responds to two of the most critical reports on child health service adds to its importance. It provides the NHS with measures to assess the quality of service provided for children and mothers.

Children have been invisible in the NHS. Until now they have been regarded as an addendum to adult services. In the NHS Plan children were largely ignored. ${ }^{4}$ Recent reforms have focused on adult services, with targets set by government to achieve them. One can argue that, as patients, pregnant women and children benefited from these reforms in terms of quantitative measures such as waiting times. However, the care of children requires a clearer vision in the more difficult qualitative areas. The national service framework emphasises that the majority of service needs for children are in the community and can only be provided by the NHS in partnership with education and social services as envisaged in Every Child Matters and the Children's Bill. ${ }^{5}$

The national service framework provides the opportunity for service developments that allow the holistic needs of children and pregnant mothers to be met. Key to this is the recognition that children and young people are different and individuals in their own right, with specific requirements which can be met only by reorganisation of service delivery. This requires a change in how health professionals and managers view maternal and child health and a reassessment of how parents, children, and young people participate in and are consulted in planning services.

The national service framework sets out a comprehensive, long term (10 year) agenda for change and a framework for healthcare provision in the broadest context. Its 11 standards for care, applying to children (defined as under 19 years) and their families, cover all aspects of NHS care including maternal health and primary care. It is encouraging that mental health is a constant strand, and that maternal health is seen as part of the continuum of health care. Key features include better consultation with children and families; changes towards care focused on children and women; and facilities designed for children with input from children and parents. A central concept is of services designed around the child's journey, to meet children's approaches including proper engagement with the voluntary sector.

The earlier framework for hospital services implied that NHS trusts needed to critically examine services for children. ${ }^{6}$ It inferred that reallocation of resources was needed, along with reconfiguration of service provision and incorporation of the overriding principles in all new hospital design and development. Change in how children are currently seen within adult services is also required. Children must be seen as important users, and their needs given similar weight to those of adults.

The impact of the national service framework on out of hospital services will be huge, especially with the emerging public health agenda. ${ }^{7}$ Primary care trusts have a central role in ensuring that the needs of mothers and children are addressed. Community based services must look at how they are organised and relate to other non-health services, including social care and education. Recent high profile cases around child abuse and child deaths highlight the needs of the most vulnerable in our society, and this is emphasised in the framework. Current concerns about the future of community child health should be noted. ${ }^{8}$ The national service framework suggests strengthening of out of hospital services, and commissioners must consider how they can use and develop current services. The challenge for general practice is also clear. Despite the absence of specifics in their new contract, the role of primary care in the development of better services for children is critical, and the national service framework sets out this agenda.

Development of tool kits to help organisations assess their current status against the national service framework and to measure progress is a priority. The lack of set targets and a clear budget stream is a criticism that can be levied at the document. Like all documents it is a compromise, a balance between the desired and the possible. However, the message is clear-we need a radical shift in our mindset towards children and we must develop a society where maternal and child health is a priority and not a luxury.

The vision of the national service framework is huge and implies considerable cultural change in the NHS, and beyond. The aim is child and family centred services, designed and delivered around their needs rather than those of organisations. The NHS must grasp this opportunity. The national service framework is government policy, strengthened by concurrent reports, and signals a higher priority for children and 
maternity services across all areas of government. ${ }^{9}{ }^{10}$ If the service and all clinicians working with women and children do not respond, children will be the losers.

Peter Lachman consultant paediatrician

North West London NHS Trust, Harrow, Middlesex HA1 3UJ (peter.lachman@nwlh.nhs.uk)

\section{David Vickers consultant community paediatrician}

South Cambridgeshire Primary Care Trust, Ida Darwin, Fulbourn, Cambridge CB1 5EE

(david.vickers@southcambridgeshire-pct.nhs.uk)

Competing interests: None declared.

1 Department of Health. National service framework for children, young people and maternity services. The Stationery Office. September 2004 www.dh.gov.uk/PolicyAndGuidance/HealthAndSocialCareTopics/ ChildrenServices/ChildrenServicesInformation/fs/en (accessed $17 \mathrm{Sep}$ 2004).

2 Kennedy I. The report of the public health inquiry into children's heart surgery at the Bristol Royal Infirmary 1984-1985. London: Stationery Office, 2001.
3 Laming WH. The Victoria Climbie report. London: Stationery Office, 2003. www.victoria-climbie-inquiry.org.uk/finreport/finreport.htm (accessed 17 Sep 2004). (Cm 5730.)

4 Department of Health. The NHS Plan: a plan for investment, a plan for reform. London: Stationery Office, July 2000. www.dh.gov.uk/assetRoot/ 04/05/57/83/04055783.pdf (accessed 17Sep 2004).

5 Department of Education and Skill. Every Child Matters. London: Stationery Office, 2003. www.dfes.gov.uk/everychildmatters/ (accessed 17 Sep 2004).

6 Department of Health. Getting the right start: national service framework for children, young people and maternity services. Part 1: standard for hospital service. London: Stationery Office, 2003.

7 Blair M, Waterstone T, Stewart-Brown S, Crowther R. Child public health. Oxford University Press, 2003.

8 Mather M. Community paediatrics in crisis. Arch Dis Child 2004;89:697704.

9 Healthcare Commission. 2004 State of Healthcare Report. July 2004. www.healthcarecommission.org.uk/NationalFindings/StateOf Healthcare/fs/en?CONTENT_ID $=4006361 \&$ chk $=$ sNVkqk (accessed 21 Sep 2004).

10 Department of Health. National standards, local action: health and social care standards and planning framework 2005/06-2007/08. London: Stationery Office, 2004. www.dh.gov.uk/assetRoot/04/08/60/58/04086058.pdf (accessed 17 Sep 2004).

\title{
Back pain and physiotherapy
}

\author{
NHS treatment is of little value
}

$\mathrm{M}$ y next patient: looking hopeful, hobbling in. Six weeks of pain and no respite. Referral to physiotherapy was the obvious option for such patients, but now I know from a paper in this issue that providing routine physiotherapy in the NHS is no better than advice to remain active (p 708). ${ }^{1}$ Six weeks is a long time to be in pain, unable to work, and relatively immobile. Most patients will still be experiencing low back pain and related disability one year after their first consultation, and unfortunately we can do little about it. ${ }^{\text {w1 }}$ Although in this study patients felt better, objective outcomes did not improve-and, in a resource limited health service, can we make referral decisions based on subjective measures?

What are the implications for physiotherapy? Not all interventions can stand up to critical appraisal, ${ }^{2}$ and this paper shows that our traditional model of physiotherapy for back pain is ineffective. But let us look more closely at this study. ${ }^{1}$ The control group had a physical examination and was given general advice to remain active, in a session that lasted one hour. This is not a "no treatment" option, and what this study shows is that the additional treatment or usual treatment available in typical physiotherapy departments in the NHS was ineffective. The treatment strategy itself, however, was dependent on the physiotherapist. Each therapist chose a treatment based on his or her findings. But the study had 76 physiotherapists-a heterogeneous group, each with different training and background. Patients in the intervention arm had various treatments, including interventions that are inherently very different, such as mobility and strengthening, heat and cold, and combinations of treatment in no particular order. An optimistic interpretation of the study may be that this strategy of ad hoc treatment is ineffective, although some component interventions could still be effective. This study confirms only that physiotherapy given in an NHS department adds little to the management of back pain, and we need to look more closely at individual treatment options before deciding that all physiotherapy for back pain is ineffective. Progressive exercise classes run by a physiotherapist have been shown to help, but spinal manipulative therapy seems not to produce clinically worthwhile changes in pain or function..$^{3-5}$

What are the options for the general practitioner? Pain relief, anti-inflammatory drugs, and reassurance that the pain is self limiting, looks fine in writing. But the annual consultation rate for acute low back pain is at least 35 per 1000 adults. ${ }^{6}$ That we have no answers for a common condition comes as a surprise to a frustrated patient with high expectations of medical intervention. The Royal College of General Practitioners has issued guidelines for the management of acute back pain, and advice is available from the Clinical Standards Advisory Group. Although management by general practitioners does not always match the guidelines, physiotherapy has always been an important component. ${ }^{78}$ w2 Radiography is not recommended, except in particular circumstances where serious illness is suspected (known as red flag indications) and helps little, and orthopaedic surgeons don't wish to see patients with low back pain where surgery is not an option. ${ }^{9}$ w3 General practitioners have few alternatives, which leads to frustration on all sides, unsatisfactory consultations, and unhappy patients.

What are the alternatives for the patient? The best option is to follow an advice sheet and remain active. If the best outcomes are from exercise then perhaps we need a new model of health care for patients with back pain. ${ }^{10}$ Perhaps we should attempt to demedicalise back pain and refer patients to specially trained fitness instructors at a gym. Patients may have other ideas and are often anxious about physical activity with back pain. ${ }^{11}$ In the study by Frost et al, although the validated

Additional references w1-w3 are on bmj.com 